\title{
Criminal Responsibility and its History
}

\author{
R. A. Duff · Susanna Blumenthal
}

Published online: 26 September 2014

(C) Springer Science+Business Media Dordrecht 2014

The original versions of the five papers in this Symposium were delivered and discussed at a workshop at the University of Minnesota Law School on Criminal Responsibility and its History. One of the aims of the workshop was to bring together scholars working on the history of the criminal law and scholars whose main focus is on issues in normative criminal law theory, to explore the ways in which they can learn from each other, and to promote a kind of dialogue between historical and normative theorising that is still too rare. Elizabeth Kamali's exploration of the idea of felony in early English law, and Thomas A Green's work on the Anglo-American jury, remind us of the importance of looking at the history of our contemporary institutions and concepts: we can understand the law that we now have only by attending to continuities and discontinuities in thought and practice that have marked its long, complex political and social history. Informed by the institutional and conceptual frameworks that shape contemporary criminal law, these historical analyses map out important shifts in the meaning of human freedom and responsibility. The papers from Alan Norrie, on the continuing significance of the ideas of good and evil in criminal law, and from Ekow Yankah, on the need to ground a normative understanding of criminal law in a kind of republicanism that finds its roots in Aristotle, show how a grasp of the history both of ideas and of institutions can enrich contemporary normative debates. Finally, Nicole Vincent's paper, on the challenge of developing a plausible version of compatibilism through which we can reconcile criminal responsibility with the findings of neuroscience, exemplifies the way in which historical developments outside the law help to shape the character of debates within the law about the conditions (indeed, the possibility) of criminal responsibility.

Grateful thanks are due to all the participants in the workshop, especially to those who provided comments on the papers (Lindsay Farmer, Mirelle Hildebrandt, Nicola Lacey,

R. A. Duff · S. Blumenthal ( $\square)$

Minneapolis, MN, USA

e-mail: blume047@umn.edu 
Arlie Loughnan, George Pavlich, Dan Richman, Jonathan Simon, Martha Umphrey, Frieder Vogelmann, Gary Watson); and to the Robina Institute of Criminal Law and Criminal Justice, which organised and funded the workshop. 